\title{
Effects of GH treatment in GH-deficient adults on adiponectin, leptin and pregnancy-associated plasma protein-A
}

\author{
C Joaquin ${ }^{1}$, E Aguilera $^{1}$, M L Granada ${ }^{2}$, M C Pastor $^{3}$, I Salinas ${ }^{1}, \mathrm{~N}$ Alonso $^{1}$ and A Sanmarti ${ }^{1}$ \\ ${ }^{1}$ Department of Endocrinology, Diabetes and Nutrition, ${ }^{2}$ Hormone Laboratory and ${ }^{3}$ Biochemical Laboratory, Department of Medicine, Hospital Universitari \\ Germans Trias i Pujol, Universitat Autonoma de Barcelona, Carretera del Canyet s/n 08916, Badalona, Barcelona, Spain
}

(Correspondence should be addressed to C Joaquin; Email: clara.joaquim@gmail.com)

\begin{abstract}
Objective: GH deficiency (GHD) in adults is associated with adverse effects on metabolism and increased cardiovascular risk. Pregnancy-associated plasma protein-A (PAPP-A) is a protease that promotes IGF-I availability in vascular tissues. PAPP-A levels appear to correlate with carotid intima-media thickness and have been proposed as an early predictor of cardiac events. The aim of our study was to evaluate PAPP-A levels in GHD adults at baseline and after GH replacement and correlate them with changes in body composition, lipid profile, glucose homeostasis, inflammatory markers and in leptin and adiponectin.

Patients and methods: Fourteen GHD adults were evaluated at baseline and after 1 year of GH therapy. All patients were compared at baseline with 28 age-, sex- and body mass index (BMI)-matched control subjects.

Results: At baseline, GHD adults showed higher PAPP-A levels $(P=0.03)$ and higher leptin $(P=0.04)$, fibrinogen $(P=0.002)$ and highly sensitive $C$-reactive protein $(P=0.01)$ values than controls. Therapy with GH reduced PAPP-A $(P=0.03)$ and fibrinogen levels $(P=0.002)$ while increased BMI $(P=0.01)$ and reduced waist-hip ratio (WHR; $P=0.05)$ were observed. Insulin and homeostasis model assessment of insulin resistance index increased after treatment $(P<0.004 / P=0.007)$, without changes in leptin or adiponectin levels. PAPP-A values correlated positively with BMI and WHR and negatively with adiponectin before and after treatment, with no correlation with glucose homeostasis parameters, lipid profile or leptin.

Conclusions: Our study suggests that PAPP-A expression is increased in GHD adults, and that 1 year of GH replacement therapy is able to reduce PAPP-A levels in this population. However, further studies are required to determine whether this decrease correlates with an improvement in atherosclerosis.
\end{abstract}

European Journal of Endocrinology 158 483-490

\section{Introduction}

Accumulated evidence has shown that untreated growth hormone-deficient adults have increased cardiovascular morbidity and mortality, exhibiting a higher occurrence of atherosclerotic plaques and increased intima-media thickness (IMT) of the common carotid arteries. Cardiovascular risk factors described in this population include altered body composition with truncal adiposity, detrimental changes in lipid profile, insulin resistance and impaired exercise capacity, among others (1-4).

There is evidence that $\mathrm{GH}$ replacement in patients who acquire growth hormone deficiency (GHD) in adulthood improves some of these deleterious effects (5-7), thereby diminishing cardiovascular risk (8-10). However, most studies report unchanged insulin sensitivity after $\mathrm{GH}$ therapy when compared with baseline $(3,11,12)$. Since GH exerts a significant effect on adipocyte metabolism, it has been postulated that adipokines, such as leptin and adiponectin, may play an important role in the effects of $\mathrm{GH}$ on glucose homeostasis (13).

Pregnancy-associated plasma protein-A (PAPP-A) is a high-molecular-weight metalloproteinase produced by human artery vascular smooth muscle cells, which degrades insulin-like growth factor-binding protein-4 (IGFBP-4), increasing the levels of local unbound IGF-I (14). Although IGF-I has been considered a mediator of plaque growth, recent clinical and experimental evidence suggest that IGF-I may instead provide protection against ischaemic vascular diseases through its anti-apoptotic and anti-inflammatory activities and its action on vasodilatation and vasculogenesis (15). PAPP-A has been found to be abundantly expressed in eroded and ruptured atherosclerotic plaques, but only minimally expressed in stable plaques, and has been proposed as a marker of increased risk of atherothrombotic events in general, although elevated levels have 
been reported in patients with acute coronary syndrome (16) and ischaemic stroke (17). In addition, PAPP-A seems to be a marker for systemic atherosclerosis, although associations between PAPP-A levels and IMT (18) or atherosclerotic peripheral arterial disease (19) have been found. After experimental injury, PAPP-A and IGF-I expressions in vascular cells are increased, suggesting that activation of the PAPP-A/ IGF-I system is a part of a very early response to ischaemia aimed at increasing delivery of IGF-I to jeopardised tissues (14). Moreover, in a recent report, it has been described that individuals with low circulating IGF-I levels have a significantly increased risk of developing ischaemic heart disease during a 15-year follow-up period (20).

There is evidence that inflammation plays a crucial role in the pathogenesis of atherosclerosis. Highly sensitive C-reactive protein (hsCRP), an acute-phase protein produced predominantly by hepatocytes under the influence of cytokines, such as interleukin-6 (IL-6), has been validated as one of the best cardiovascular risk markers (21). Some studies have demonstrated that $\mathrm{GH}$ replacement in GHD adults has beneficial effects on peripheral markers of inflammatory activity such as plasma hsCRP, IL-6 and fibrinogen (22-24).

The aim of this prospective open-design study was to evaluate PAPP-A levels in GHD adults at baseline and after 1 year of $\mathrm{GH}$ replacement and correlate them with changes in body composition, lipid profile, glucose homeostasis, inflammatory markers and in leptin and adiponectin levels. To our knowledge, no data on serum PAPP-A concentrations in GHD patients have been reported.

\section{Patients and methods}

Fourteen adult-onset GHD subjects (five men/nine women) considered for GH replacement therapy were evaluated. The characteristics of these patients are described in Table 1. All patients had complete pituitary insufficiency, with a mean duration of GHD at enrolment of 19.1 months (range: 14-26 months). Panhypopituitarism was due to pituitary nonfunctioning adenoma $(n=10)$, hypothalamic tumour $(n=2)$, empty sella syndrome $(n=1)$ and autoimmune hypophysitis $(n=1)$. All patients with a pituitary or hypothalamic tumour underwent surgery, and eight patients with pituitary adenoma also received radiotherapy. A GH peak $<3 \mu \mathrm{g} / \mathrm{l}$ confirmed the diagnosis of GHD during insulin-induced hypoglycaemia. All women under $50 \quad(n=6)$ were on transdermal oestrogen replacement therapy and all men were receiving testosterone. Other hormone deficiencies were adequately replaced for at least 12 months before enrolment, with stable doses being maintained during the study period. Adrenocorticotrophin- and thyrotrophin-deficient patients were treated orally with three daily doses of hydrocortisone acetate $(20-30 \mathrm{mg} /$ day $)$ and one dose of levothyroxine (50-150 $\mu \mathrm{g} /$ day) respectively. Desmopressin was given when necessary. No patient received fludrocortisone. Adequacy of replacement therapy was periodically assessed by measuring serum-free thyroid hormones, testosterone, urinary free cortisol and blood pressure. None of the patients received any other medication. Subjects with renal disease, hypertension, diabetes mellitus or previous cardiovascular events were not eligible for the study.

Table 1 Comparison of clinical and biochemical characteristics of growth hormone deficiency (GHD) patients and control subjects at baseline.

\begin{tabular}{|c|c|c|c|}
\hline & GHD patients $(n=14)$ & Controls $(n=28)$ & $\boldsymbol{P}$ \\
\hline Age (years) & $40.80 \pm 14.40$ & $43.20 \pm 11.60$ & NS \\
\hline Body weight (kg) & $67.90 \pm 13.69$ & $74.36 \pm 14.11$ & NS \\
\hline BMI $\left(\mathrm{kg} / \mathrm{m}^{2}\right)$ & $26.41 \pm 3.91$ & $27.5 \pm 3.07$ & NS \\
\hline WHR & $0.89 \pm 0.07$ & $0.87 \pm 0.08$ & NS \\
\hline $\mathrm{SBP}(\mathrm{mmHg})$ & $111.62 \pm 12.01$ & $122.45 \pm 14.32$ & NS \\
\hline $\mathrm{DBP}(\mathrm{mmHg})$ & $64.00 \pm 8.00$ & $73.36 \pm 9.66$ & $0.02^{*}$ \\
\hline $\mathrm{FPG}(\mathrm{mmol} / \mathrm{l})$ & $4.81+0.62$ & $5.17+0.82$ & NS \\
\hline $\mathrm{HbA} 1 \mathrm{c}(\%)$ & $4.52 \pm 0.66$ & $4.45 \pm 0.43$ & NS \\
\hline Insulin (mIU/l) & $6.59 \pm 3.74$ & $8.27 \pm 2.84$ & NS \\
\hline HOMA-IR index & $1.44 \pm 0.88$ & $1.85 \pm 0.73$ & NS \\
\hline Total cholesterol (mg/dl) & $216.66 \pm 48.53$ & $222.10 \pm 43.00$ & NS \\
\hline Triglyceride $(\mathrm{mg} / \mathrm{dl})$ & $105.50(76.75-154.00)$ & $97.00(70.00-141.50)$ & NS \\
\hline Adiponectin $(\mu \mathrm{g} / \mathrm{ml})$ & $7.11 \pm 3.32$ & $11.55 \pm 7.89$ & NS \\
\hline Leptin $(\mathrm{ng} / \mathrm{ml})$ & $24.69+16.12$ & $13.69+12.01$ & $0.04^{*}$ \\
\hline PAPP-A $(\mu \mathrm{lU} / \mathrm{ml})$ & $1.22 \pm 0.83$ & $0.92 \pm 0.56$ & $0.03^{*}$ \\
\hline Fibrinogen (mg/dl) & $401.41 \pm 126.41$ & $289.02 \pm 43.00$ & $0.002^{*}$ \\
\hline $\operatorname{HsCRP}(\mathrm{mg} / \mathrm{l})$ & $3.77(1.90-6.70)$ & $0.70(0.30-2.01)$ & $0.01^{*}$ \\
\hline
\end{tabular}

BMI, body mass index; WHR, waist-hip ratio; SBP, systolic blood pressure; DBP, diastolic blood pressure; FPG, fasting plasma glucose; HsCRP, highly sensitive C-reactive protein; PAPP-A, pregnancy associated plasma protein-A; NS, not significant. Data are expressed as mean \pm s.D. or median $\left(P_{25}-P_{75}\right)$. ${ }^{*} P<0.05$, by Mann-Whitney $U$ test. 
At study entry, all GHD patients had a normal electrocardiogram and no alterations were observed on cardiovascular physical examination.

All patients were evaluated at baseline and after 1 year of GH replacement therapy. The mean initial dose of recombinant human GH (Genotonorm) was $0.39 \mathrm{mg} /$ day (range: $0.20-0.80$ ), with a mean final dose of $0.47 \mathrm{mg} /$ day (range: $0.20-0.81$ ), with no differences being observed between males and females. GH doses were individually titrated to keep serum IGF-I concentrations within the normal age-related range. The large variation in GH dose at the start of the study and after 1 year of replacement was due to patients' clinical characteristics: two young adult patients, aged 18 and 19 years, required higher doses than the average in GHD adult patients. Two other patients had short stature and low weight and were thus receiving lower doses of GH.

Patients were compared at baseline with 28 healthy control subjects matched for age, sex, BMI and menopausal status, recruited from medical and paramedical personnel of our hospital. Their characteristics are described in Table 1. None of the control subjects or GHD adults had any evidence, based on medical history, of active cardiovascular or other systemic disease. The research procedures in both groups were performed in the same research unit and by the same researchers as GHD patients. Controls and GHD patients were nonsmokers and had a sedentary life style.

All patients and controls gave their written informed consent for the study, which was approved by the hospital ethics committee.

\section{Anthropometry, body composition and blood pressure measurements}

Weight, body mass index (BMI, $\mathrm{kg} / \mathrm{m}^{2}$ ) and waist-hip ratio (WHR) were calculated at baseline and 1 year after initiation of treatment. In GHD patients, body composition was measured by multifrequency bioelectrical impedance analysis (Holtain BC Analyser, Dyfed UK) before and after the treatment periods.

Blood pressure was taken in the right arm, with the subject in a relaxed sitting position. The average of three measurements with a mercury sphygmomanometer was used for analysis.

\section{Biochemical assays}

Blood samples were collected after an overnight fast and were immediately centrifuged, and serum kept frozen at $-80{ }^{\circ} \mathrm{C}$ until assayed.

Plasma glucose, cholesterol and triglycerides were determined with a routine clinical chemistry laboratory analyser. $\mathrm{HbA1c}$ was measured in blood samples with EDTA by high-pressure liquid chromatography using a fully automated Menarini HI-AUTO A1c 8140 analyser manufactured by Arkray (Kyoto, Japan) with an interassay coefficient of variation $(\mathrm{CV})$ of 3.0 and $1.8 \%$ at $\mathrm{HbA1c}$ levels of 4.8 and $9.0 \%$ respectively (reference range: 3.7-5.1\%). Immunoreactive insulin concentrations were measured using an automated enzyme chemiluminescence immunoassay (Immulite 2000, DPC, Los Angeles, CA, USA). Assay sensitivity was $2 \mathrm{mIU} / \mathrm{l}$. The intra- and inter-assay CV were below 5.5 and $7.3 \%$ respectively. Insulin resistance was assessed by the homeostasis model assessment of insulin resistance (HOMA-IR) and calculated from fasting plasma insulin and fasting plasma glucose concentrations as follows: HOMA-IR index $=$ fasting insulin $(\mathrm{mIU} / \mathrm{l}) \times$ fasting glucose $(\mathrm{mmol} / \mathrm{l}) / 22.5$. Serum IGF-I was measured by RIA after separation of the binding proteins by acid-ethanol precipitation (Nichols Institute Diagnostics, San Juan Capistrano, CA, USA). The assay was calibrated against international reference preparation $87 / 518$. Intra-assay CV was 6.3 and $4.9 \%$, and inter-assay CV was 12.3 and $6.8 \%$ for IGF-I concentrations of 100.1 and $177.2 \mu \mathrm{g} / \mathrm{l}$ respectively. Assay sensitivity was $13.5 \mu \mathrm{g} / \mathrm{l}$. Serum adiponectin concentrations were measured with a commercial double antibody RIA (Linco Research Inc., St Louis, MO, USA) with intra- and inter-assay CV below 6.2 and $9.2 \%$ respectively. Assay sensitivity was $1 \mu \mathrm{g} / \mathrm{ml}$. All plasma samples were diluted 1:250 to yield an effective range of $0.2-50 \mu \mathrm{g} / \mathrm{ml}$. Serum leptin concentrations were measured with a commercial RIA (Linco Research Inc.) with intra- and inter-assay CV of 3.4-8.3 and 3.6$6.2 \%$ respectively. The sensitivity of the assay was $0.5 \mathrm{ng} / \mathrm{ml}$. The reference range (median; 5th-95th percentiles) for leptin obtained in normal-weight women was $10.4 \mathrm{ng} / \mathrm{ml}(2.8-37.6 \mathrm{ng} / \mathrm{ml})$ and in normal-weight men $3.7 \mathrm{ng} / \mathrm{ml}(1.2-9.2 \mathrm{ng} / \mathrm{ml})$. Serum CRP concentrations were measured using an ultrasensitive CRP test ( $\mathrm{N}$ high-sensitivity $\mathrm{CRP}$ ) on a BP-ProSpec nephelometer (Dade Behring, GMBH, Marburg, Germany) with an inter-assay CV of 3.7 and 3.5\% for CRP concentrations of 2.38 and $52.2 \mathrm{mg} / \mathrm{l}$ respectively. The sensitivity of the assay was $0.175 \mathrm{mg} / \mathrm{l}$, performed using a sample dilution of 1:20. Serum IL-6 concentrations were measured using an enzyme chemiluminescence immunometric assay (Immulite, DPC) with an inter-assay CV of 3.75 and $5.9 \%$ for IL-6 concentration of 78.5 and $460.0 \mathrm{pg} / \mathrm{ml}$ respectively. Fibrinogen was measured by coagulometrynephelometry. Ultrasensitive PAPP-A was measured in serum using an ELISA (DSL, Active US PAPP-A ELISA Diagnostic Systems Laboratories Inc., Webster, TX, USA) with an inter-assay CV of 8.5 and $5.3 \%$ for PAPP-A concentrations of 2.5 and $10 \mathrm{mIU} / \mathrm{l}$ respectively.

\section{Statistical analysis}

Descriptive results are expressed as mean \pm s.D. or median (interquartile range). Departure from normality 
was assessed by the Kolmogorov-Smirnov distribution test. Comparisons between groups were made using the Mann-Whitney $U$ test. The Wilcoxon test was used to compare quantitative variables before and after $\mathrm{GH}$ treatment. Relationships among variables were tested by Spearman's correlation coefficient. IGF-I results were expressed as SDS from the age-related reference population. The number of SDS from the age-related reference population mean was calculated for each value: $\mathrm{SDS}=(\mathrm{Ln}$ value - mean of the $\mathrm{Ln}$ values $) /$ s.D. of the Ln values. A $P$ value $<0.05$ was considered statistically significant. All statistical calculations were performed using the Statistical Package for Social Science (SPSS) for personal computers, version 12.0 (SPSS, Chicago, IL, USA).

\section{Results} Comparison at baseline between GHD patients
and control subjects

At baseline, diastolic blood pressure was lower in GHD patients than in controls $(64.00 \pm 8.00$ vs $73.36 \pm$ $9.66 \mathrm{mmHg} ; P=0.02$ ), but no statistical differences were observed in systolic blood pressure. Neither were significant differences found in weight, WHR, fasting plasma glucose, HbA1c, insulin, HOMA-IR, serum total cholesterol, triglycerides and adiponectin. PAPP-A concentrations were significantly higher in GHD patients than in control subjects $(1.22 \pm 0.83$ vs $0.92 \pm$ $0.56 \mu \mathrm{IU} / \mathrm{ml} ; P=0.03)$. Serum leptin $(24.69 \pm 16.12 \mathrm{vs}$ $13.69 \pm 12.01 \mathrm{ng} / \mathrm{ml} ; P=0.04)$, fibrinogen $(401.41 \pm$ 126.41 vs $289.02 \pm 43.00 \mathrm{mg} / \mathrm{dl} ; P=0.002)$ and hsCRP (3.77 (1.90-6.70) vs $0.70(0.30-2.01) \mathrm{mg} / \mathrm{l} ; P=0.01)$ levels were also higher in patients than in controls. Results are shown in Table 1.

\section{Effects of GH treatment}

After 1 year of GH replacement, weight $(67.90 \pm 13.69$ vs $69.70 \pm 13.7 \mathrm{~kg} ; P=0.03)$ and BMI $(26.41 \pm 3.91$ vs $\left.27.27 \pm 3.62 \mathrm{~kg} / \mathrm{m}^{2} ; P=0.01\right)$ increased while WHR decreased almost significantly $(0.89 \pm 0.07$ vs $0.87 \pm$ $0.05 ; P=0.050)$. Insulin concentrations $(6.59 \pm 3.74$ vs $10.46 \pm 7.00 \mathrm{mIU} / \mathrm{l} ; P=0.004)$ and HOMA-IR index $(1.44 \pm 0.88$ vs $2.46 \pm 1.74 ; P=0.007)$ were significantly higher after replacement. No differences were observed in glucose levels, HbAlc, lipid profile, adiponectin and leptin levels before and after $\mathrm{GH}$ treatment. Fibrinogen decreased significantly after 1 year of GH therapy $(401.41 \pm 126.41$ vs $318.92 \pm$ $92.20 \mathrm{mg} / \mathrm{dl} ; P=0.002$ ), but no significant changes were found in hsCRP or IL-6, although they showed a tendency towards a decrease. Serum PAPP-A concentrations were significantly lower after 1 year of $\mathrm{GH}$ replacement $(1.22 \pm 0.83$ vs $0.99 \pm 0.66 \mu \mathrm{IU} / \mathrm{ml}$; $P=0.03)$. Results are shown in Tables 2 and 3 .
Table 2 Changes in body composition and blood pressure after 1 year of growth hormone $(\mathrm{GH})$ replacement therapy in $\mathrm{GH}$ deficiency (GHD) adults.

\begin{tabular}{lccc}
\hline $\boldsymbol{n}=\mathbf{1 4}$ & Baseline & 1 year & $\boldsymbol{P}$ \\
\hline Body weight $(\mathrm{kg})$ & $67.90 \pm 13.69$ & $69.70 \pm 13.7$ & $0.03^{*}$ \\
BMI $\left(\mathrm{kg} / \mathrm{m}^{2}\right)$ & $26.41 \pm 3.91$ & $27.27 \pm 3.62$ & $0.01^{*}$ \\
WHR & $0.89 \pm 0.07$ & $0.87 \pm 0.05$ & $0.05^{*}$ \\
Fat-free mass $(\mathrm{kg})$ & $59.27 \pm 16.25$ & $60.57 \pm 16.67$ & $\mathrm{NS}$ \\
Fat mass $(\mathrm{kg})$ & $25.05 \pm 19.77$ & $24.07 \pm 20.74$ & $\mathrm{NS}$ \\
SBP $(\mathrm{mmHg})$ & $111.62 \pm 12.01$ & $118.83 \pm 16.54$ & $\mathrm{NS}$ \\
DBP $(\mathrm{mmHg})$ & $64.00 \pm 8.00$ & $70.71 \pm 7.43$ & $\mathrm{NS}$ \\
\hline
\end{tabular}

BMI, body mass index; WHR, waist-hip ratio; SBP, systolic blood pressure; DBP, diastolic blood pressure and NS, not significant. Data are expressed as mean \pm S.D. ${ }^{\star} P<0.05$, by Wilcoxon test for quantitative variables.

\section{Relationships among PAPP-A, body composition, adipokines, parameters of glucose metabolism, inflammatory markers and lipid profile}

In GHD patients, PAPP-A correlated positively with BMI at baseline $(r=0.57 ; P=0.03)$ and after $\mathrm{GH}$ therapy $(r=0.66 ; P=0.01)$ and also with WHR before $(r=0.58$; $P=0.04)$ and after replacement $(r=0.67 ; P=0.02)$. Adiponectin levels correlated inversely with PAPP-A at baseline $(r=-0.53 ; P=0.04)$. No other relationship was observed between PAPP-A concentrations and the other parameters studied, and neither between $\triangle$ PAPP-A and changes in IGF-I, inflammatory markers, BMI or WHR. Glucose homeostasis parameters and lipid profile did not correlate with leptin and adiponectin levels.

\section{Discussion}

The main findings of the present study were that PAPP-A serum concentrations, which seem to be a marker for systemic atherosclerosis, were higher in GHD patients than in controls and that $\mathrm{GH}$ replacement was able to lower PAPP-A levels in these patients. To our knowledge, this is the first study to analyse serum PAPP-A levels in GHD adults. At baseline, as was expected owing to the increased risk of atherosclerosis in the GHD population, our GHD patients exhibited higher PAPP-A levels than controls. Although the effects of GHD on vascular tissues in our cohort might have been mild at baseline due to the short duration of hypopituitarism, PAPP-A could have acted as a marker of subclinical atherosclerosis. After 1 year of $\mathrm{GH}$ replacement, PAPP-A concentrations decreased significantly, which could suggest that GH replacement in GHD adults may reduce progression of atherosclerotic plaques. In agreement with our findings, a recent study reported an improvement in endothelial function and a reduction in arterial stiffness after $\mathrm{GH}$ replacement (25). Moreover, another study of 36 adult-onset GHD patients who received $\mathrm{GH}$ replacement for 2 years showed a 
Table 3 Changes in glucose metabolism, lipid profile, circulating adipokines, inflammatory markers and pregnancy-associated plasma protein-A (PAPP-A) concentrations after 1 year of growth hormone (GH) replacement therapy in GH deficiency (GHD) adults.

\begin{tabular}{lccc}
\hline $\boldsymbol{n}=\mathbf{1 4}$ & Baseline & 1 year & \multicolumn{1}{c}{$\boldsymbol{P}$} \\
\hline FPG $(\mathrm{mmol} / \mathrm{l})$ & $4.81 \pm 0.62$ & $5.08 \pm 0.88$ & $\mathrm{NS}$ \\
HbA1c $(\%)$ & $4.52 \pm 0.66$ & $4.52 \pm 1.62$ & $\mathrm{NS}$ \\
Insulin $(\mathrm{mlU} / \mathrm{l})$ & $6.59 \pm 3.74$ & $10.46 \pm 7.00$ & $0.004^{*}$ \\
HOMA-IR index & $1.44 \pm 0.88$ & $2.46 \pm 1.74$ & $\mathrm{~N}$ \\
Total cholesterol $(\mathrm{mg} / \mathrm{dl})$ & $216.66 \pm 48.53$ & $181.55 \pm 47.45$ & $\mathrm{NS}$ \\
Triglyceride $(\mathrm{mg} / \mathrm{dl})$ & $105.50(76.75-154.00)$ & $149.00(80.50-185.75)$ & $\mathrm{NS}$ \\
Adiponectin $(\mu \mathrm{g} / \mathrm{ml})$ & $7.11 \pm 3.32$ & $6.65 \pm 3.73$ & $\mathrm{NS}$ \\
Leptin $(\mathrm{ng} / \mathrm{ml})$ & $24.69 \pm 16.12$ & $26.12 \pm 16.49$ & $0.07^{*}$ \\
PAPP-A $(\mu / \mathrm{l} / \mathrm{ml})$ & $1.22 \pm 0.83$ & $0.99 \pm 0.66$ & $0.002^{*}$ \\
IGF-I $(\mathrm{ng} / \mathrm{ml})$ & $54.48 \pm 40.80$ & $235.72 \pm 118.80$ & $0.001^{*}$ \\
IGF-I SDS & $-4.55 \pm 1.99$ & $-0.26 \pm 0.90$ & $0.002^{*}$ \\
Fibrinogen $(\mathrm{mg} / \mathrm{dl})$ & $401.41 \pm 126.41$ & $318.92 \pm 92.20$ & $\mathrm{NS}$ \\
IL-6 $(\mathrm{pg} / \mathrm{ml})$ & $2.66 \pm 0.75$ & $2.37 \pm 0.63$ & $\mathrm{NS}$ \\
HsCRP $(\mathrm{mg} / \mathrm{l})$ & $3.77(1.90-6.70)$ & $2.60(1.73-4.75)$ & \\
\hline
\end{tabular}

FPG, fasting plasma glucose; IGF-I SDS, IGF-I standard deviation score; IL-6, interleukin-6; HsCRP, highly sensitive C-reactive protein; NS, not significant. Data are expressed as mean \pm s.D. or median $\left(P_{25}-P_{75}\right)$. ${ }^{\star} P<0.05$, by Wilcoxon test.

decrease in IMT of common carotid arteries (10), further supporting the results, suggesting that $\mathrm{GH}$ therapy may improve early atherosclerotic vascular alterations.

Nevertheless, as PAPP-A is a protease that increases IGF-I bioavailability in tissues by cleaving IGFBP-4, elevated PAPP-A levels in GHD adults could be a response to IGF-I deficiency. GH replacement has been shown to normalise IGF-I, thereby improving vascular reactivity (3). In our patients, GH therapy could have lowered PAPP-A concentrations perhaps as a response to a major IGF-I availability. However, we could not find a relationship between changes in IGF-I and changes in PAPP-A levels.

Based on the evidence, protein markers of inflammation have been studied as non-invasive indicators of underlying atherosclerosis in apparently healthy individuals. In our study, we analysed these inflammation parameters as other markers of atherosclerotic vascular disease besides PAPP-A. Some studies have demonstrated that $\mathrm{GH}$ replacement in GHD patients has beneficial effects on peripheral proteins of inflammatory activity such as fibrinogen, hsCRP and IL-6 (22-24). However, other authors have reported no changes in these markers after GH therapy (26-28).

Plasma fibrinogen level seems to be an important predictor of cardiovascular disease. In a recent large meta-analysis, a log-linear relationship was found between plasma fibrinogen and vascular heart disease, stroke and mortality due to other cardiovascular events (29). In our GHD cohort, fibrinogen levels at baseline were higher than in controls, and decreased significantly after 1 year of GH replacement, thus supporting the notion that GH treatment in GHD adults could reduce cardiovascular risk. Nevertheless, we were unable to find a correlation between PAPP-A concentrations and fibrinogen levels at baseline or at the end of the study.
A statement from the Centers for Disease Control and Prevention and the American Heart Association concluded that hsCRP levels $>3 \mathrm{mg} / \mathrm{l}$ could estimate high cardiovascular risk (30). As reported by other authors (28), our GHD adults showed at baseline elevated hsCRP levels, significantly higher than controls, which may put them at high cardiovascular risk. GH therapy lowered hsCRP levels practically to normal range, although changes were not significant. Changes in IL-6 concentrations did not reach statistical significance either (Table 3). This slight but not significant decrease in hsCRP and IL- 6 levels could have been due to an increased HOMA-IR index after GH replacement, though emerging laboratory and epidemiological data show strong associations between insulin resistance and hsCRP and IL- 6 levels $(31,32)$.

Although BMI increased after GH therapy, WHR decreased compared with basal measurements. This may reflect an effect of $\mathrm{GH}$ on limiting central body fat deposition, thereby preventing the increase in WHR that occurs in untreated patients (33), which confers on them a higher cardiovascular risk. Interestingly, in our GHD adults, PAPP-A levels correlated positively with BMI and WHR before and after treatment. As abdominal obesity is associated with higher cardiovascular morbidity and mortality, these findings support the notion that PAPP-A could be a marker of atherosclerosis in GHD patients.

In accordance with recent reports of short-term GH replacement, we observed no changes in cholesterol and triglyceride concentrations after 1 year of treatment $(3,6)$. Nonetheless, other longer studies observed a beneficial effect of GH therapy on GHD dyslipidaemia $(7,10)$. The association between PAPP-A and cholesterol levels is controversial. In our series, we were unable to find any association between cholesterol or triglyceride concentrations and PAPP-A before and after $\mathrm{GH}$ treatment. 
Insulin concentrations and the HOMA-IR index increased after $\mathrm{GH}$ replacement in our patients, although no changes were observed in fasting plasma glucose. Recently, some authors found no changes or impairment in insulin sensitivity after short-term GH treatment $(11,12)$ while, in contrast to our findings, other reports described an improvement in insulin sensitivity after GH therapy $(10,23)$. No relationship between PAPP-A and glucose homeostasis parameters was found in our patients. In a previous study, Aso et al. (18) observed higher PAPP-A levels in diabetic patients with an elevated $\mathrm{HbAlc}$ mean $(9.6 \pm 2 \%)$ than in controls, but no relationship between PAPP-A and glycaemic control was evaluated. In contrast, a recent report (34), observed an inverse correlation between PAPP-A and $\mathrm{HbA} 1 \mathrm{c}$ in diabetic patients. All our patients had $\mathrm{HbA1c}$ levels within normal range; thus, it is possible that PAPP-A concentrations only correlate with $\mathrm{HbA1c}$ when glycaemic control is poor.

In the present study, leptin levels were higher in GHD patients than in controls, which may reflect an increased amount of total body fat. Nevertheless, this cannot be further demonstrated from our study, since fat mass and lean body mass data were unfortunately not available for our controls. No significant differences in leptin levels were found after GH replacement. Some authors have reported that serum leptin concentrations correlate more strongly with s.c. than with visceral fat, though leptin secretion is greater in s.c. adipose tissue (35). Although WHR decreased after GH therapy in our patients, we could not find any significant changes in fat mass, which may explain the unchanged levels of leptin after 1 year of GH replacement. Nevertheless, it has been reported that 1 year of GH replacement does not affect leptin concentrations, despite a reduction in body fat $(3,12,36)$.

Adiponectin concentrations seem to be influenced by multiple factors, with a negative correlation with BMI being observed (37). In our cohort, no differences were found in total serum adiponectin levels between controls and GHD subjects, possibly because they were matched for age, sex and BMI. On the other hand, adiponectin levels correlate strongly with insulin resistance (38), and in our study population, no differences were found in glucose homeostasis between groups. According to previous reports $(3,39)$, adiponectin levels did not change during GH treatment. It is interesting to note that although insulin resistance was impaired after GH therapy, adiponectin levels did not vary, perhaps due to the lack of significant changes in fat mass, which suggests that adiponectin does not play an important role in insulin sensitivity of GHD adults. We observed a negative correlation between PAPP-A and adiponectin, probably because PAPP-A correlated positively with BMI in our patients.

In summary, despite the low number of patients evaluated, our study suggests that untreated GHD adults have enhanced PAPP-A expression that could be reduced by GH therapy. However, the mechanisms responsible for this reduction remain to be determined, and could be a matter of debate, thus PAPP-A could act in GH-deficient adults as a marker of early onset atherosclerosis or as a response to IGF-I deficiency. The administration of GH in our GHD cohort did not produce any significant changes in leptin and adiponectin levels, although there was impairment in insulin resistance, which suggests that these adipocytokines do not play an important role in glucose homeostasis in GHD adults. Further and larger studies are required to determine whether the decrease in PAPP-A levels in GHD patients leads to an improvement in atherosclerosis and a reduction in cardiovascular events.

\section{References}

1 Hoffman AR, Kuntze JE, Baptista J, Baum HB, Buamann GP, Biller BM, Clark RV, Cook D, Inzucchi SE, Kleinberg D, Klibanski A, Phillips LS, Ridgway EC, Robbins RJ, Schlechte J, Sharma M, Thorner MO \& Vance ML. Growth hormone (GH) replacement therapy in adult-onset GH deficiency: effects on body composition in men and women in a double-blind, randomized, placebocontrolled trial. Journal of Clinical Endocrinology and Metabolism $2004892048-2056$.

2 Badia X, Lucas A, Sanmarti A, Roset M \& Ulied A. One-year followup of quality of life in adults with untreated growth hormone deficiency. Clinical Endocrinology 199849 765-771.

3 Hana V, Silha JV, Justova V, Lacinova Z, Stepan JJ \& Murphy LJ. The effects of GH replacement in adult GH-deficient patients: changes in body composition without concomitant changes in the adipokines and insulin resistance. Clinical Endocrinology 200460 $442-450$.

4 Sanmarti A, Lucas A, Hawkins F, Webb SM \& Ulied A. Observational study in adult hypopituitary patients with untreated growth hormone deficiency (ODA study). Socio-economic impact and health status. Collaborative ODA (Observational GH Deficiency in Adults) Group. European Journal of Endocrinology 1999141 481-489.

5 Kelestimur F, Jonsson P, Molvalilar S, Gomez JM, Auernhammer CJ, Kolak R, Kolostowska-Haggstrom M \& Goth MI. Sheehan's syndrome: baseline characteristics and effect of 2 years of growth hormone replacement therapy in 91 patients in KIMSPfizer International Metabolic Database. European Journal of Endocrinology 2005152 581-587.

6 Benedini S, Dalle Carbonare L, Albiger N, Scanarini M, Bilora F, Petrobelli F, Giannini S, Mantero F \& Scaroni C. Effect of short-term therapy with recombinant human growth hormone $(\mathrm{GH})$ on metabolic parameters and preclinical atherosclerotic markers in hypopituitary patients with growth hormone deficiency. Hormone and Metabolic Research 200638 16-21.

7 Tanriverdi F, Unluhizarci K, Kula M, Guven M, Bayram F \& Kelestimur F. Effects of 18-month growth hormone (GH) replacement therapy in patients with Sheehan's syndrome. Growth Hormone and IGF Research 200515 231-237.

8 Colao A. Cardiovascular effects of growth hormone treatment: potential risks and benefits. Hormone Research 200462 42-50.

9 Maison P \& Chanson P. Cardiac effects of growth hormone in adults with growth hormone deficiency: a meta-analysis. Circulation $20031082648-2652$.

10 Colao A, Di Somma C, Cuocolo A, Spinelli L, Acampa W, Spiezia S, Rota F, Savanelli MC \& Lombardi G. Does a gender-related effect of growth hormone $(\mathrm{GH})$ replacement exist on cardiovascular risk factors, cardiac morphology, and performance and atherosclerosis? Results of a two-year open, prospective study in young adult men and women with severe GH deficiency Journal of Clinical Endocrinology and Metabolism 200590 5146-5155. 
11 Eden EB, Burman P, Holdstock C \& Karlsson FA. Effects of growth hormone $(\mathrm{GH})$ on ghrelin, leptin, and adiponectin in $\mathrm{GH}$-deficient patients. Journal of Clinical Endocrinology and Metabolism $2003 \mathbf{8 8}$ 5193-5198.

12 Giavoli C, Cappiello V, Corbetta S, Ronchi CL, Morpurgo PS, Ferrante E, Beck-Peccoz P \& Spada A. Different effects of short- and long-term recombinant hGH administration on ghrelin and adiponectin levels in GH-deficient adults. Clinical Endocrinology $20046181-87$.

13 Svensson J, Herlitz H, Lundberg PA \& Johannsson G. Adiponectin, leptin, and erythrocyte sodium/lithium countertransport activity, but not resistin, are related to glucose metabolism in growth hormone-deficient adults. Journal of Clinical Endocrinology and Metabolism 200590 2290-2296.

14 Conti E, Carrozza C, Capoluongo E, Volpe M, Crea F, Zuppi C \& Andreotti F. Insulin-like growth factor-1 as a vascular protective factor. Circulation $20041102260-2265$.

15 Crea F \& Andreotti F. Pregnancy-associated plasma protein A and coronary atherosclerosis: marker, friend, or foe? European Heart Journal 200526 2075-2076.

16 Heeschen C, Dimmeler S, Hamm CW, Fichtlscherer S, Simoons ML \& Zeiher AM. Pregnancy-associated plasma protein-A levels in patients with acute coronary syndromes: comparison with markers of systemic inflammation, platelet activation, and myocardial necrosis. Journal of the American College of Cardiology 200545 229-237.

17 Fialova L, Pileckova N, Bauer J, Soukupova J, Kalousova M, Malbohan I, Pernicky A, Kraml P \& Zima T. Pregnancy-associated plasma protein-A in patients with cerebrovascular diseases - a pilot study. Prague Medical Report 2006107 37-45.

18 Aso Y, Okumura K, Wakabayashi S, Takebayashi K, Taki S \& Inukai T. Elevated pregnancy-associated plasma protein-a in sera from type 2 diabetic patients with hypercholesterolemia: associations with carotid atherosclerosis and toe-brachial index. Journal of Clinical Endocrinology and Metabolism 200489 5713-5717.

19 Mueller T, Dieplinger B, Poelz W \& Haltmayer M. Increased pregnancy-associated plasma protein-A as a marker for peripheral atherosclerosis: results from the Linz Peripheral Arterial Disease Study. Clinical Chemistry 200652 1096-1103.

20 Juul A, Scheike T, Davidsen M, Gyllenborg J \& Jorgensen T. Low serum insulin-like growth factor I is associated with increased risk of ischemic heart disease: a population-based case-control study. Circulation 2002106 939-944.

21 Black S, Kushner I \& Samols D. C-reactive protein. Journal of Biological Chemistry 2004279 48487-48490.

22 McCallum RW, Sainsbury CA, Spiers A, Dominiczak AF, Petrie JR, Sattar N \& Connell JM. Growth hormone replacement reduces C-reactive protein and large-artery stiffness but does not alter endothelial function in patients with adult growth hormone deficiency. Clinical Endocrinology 200562 473-479.

23 Yuen KC, Frystyk J, White DK, Twickler TB, Koppeschaar HP, Harris PE, Fryklund L, Murgatroyd PR \& Dunger DB. Improvement in insulin sensitivity without concomitant changes in body composition and cardiovascular risk markers following fixed administration of a very low growth hormone $(\mathrm{GH})$ dose in adults with severe GH deficiency. Clinical Endocrinology 200563 428-436.

24 Sesmilo G, Biller B, Llevadot J, Hayden D, Hanson G, Rifai N \& Kilbanski A. Effects of growth hormone administration on inflammatory and other cardiovascular risk markers in men with growth hormone deficiency. Annals of Internal Medicine 2000 $133111-122$.

25 Lanes R, Soros A, Flores K, Gunczler P, Carrillo E \& Bandel J. Endothelial function, carotid artery intima-media thickness, epicardial adipose tissue, and left ventricular mass and function in growth hormone-deficient adolescents: apparent effects of growth hormone treatment on these parameters. Journal of Clinical Endocrinology and Metabolism $2005903978-3982$.

26 Gómez JM, Sahún M, Vila R, Domenech P, Catalina P, Soler J \& Badimon L. Peripheral fibrinolytic markers, soluble adhesion molecules, inflammatory cytokines and endothelial function in hypopituitary adults with growth hormone deficiency. Clinical Endocrinology $2006 \mathbf{6 4} 632-639$.

27 Abdu TA, Elhadd TA, Buch H, Barton D, Neary R \& Clayton RN. Recombinant $\mathrm{GH}$ replacement in hypopituitary adults improves endothelial cell function and reduces calculated absolute and relative coronary risk. Clinical Endocrinology $200461387-393$.

28 Hansen TK, Thiel S, Dall R, Rosenfalck AM, Trainer P, Flyvbjerg A, Jorgensen JO \& Christiansen JS. GH strongly affects serum concentrations of mannan-binding lectin: evidence for a new IGF-I independent immunomodulatory effect of GH. Journal of Clinical Endocrinology and Metabolism 200186 5383-5388.

29 Danesh J, Lewington S, Thompson SG, Lowe GD, Collins R, Kostis JB, Wilson AC, Folsom AR, Wu K, Benderly M, Goldbourt U, Willeit J, Kiechl S, Yarnell JW, Sweetnam PM, Elwood PC, Cushman M, Psaty BM, Tracy RP, Tybjaerg-Hansen A, Haverkate F, de Maat MP, Thompson SG, Fowkes FG, Lee AJ, Smith FB, Salomaa V, Harald K, Rasi R, Vahtera E, Jousilahti P, Pekkanen J, D'Agostino R, Kannel WB, Wilson PW, Tofler G, Arocha-Pinango CL, Rodriguez-Larralde A, Nagy E, Mijares M, Espinosa R, Rodriquez-Roa E, Ryder E, Diez-Ewald MP, Campos G, Fernandez V, Torres E, Coll E, Marchioli R, Valagussa F, Rosengren A, Wilhelmsen L, Lappas G, Eriksson H, Cremer P, Nagel D, Curb JD, Rodriguez B, Yano K, Salonen JT, Nyyssonen K, Tuomainen TP, Hedblad B, Lind P, Loewel H, Koenig W, Meade TW, Cooper JA, De Stavola B, Knottenbelt C, Miller GJ, Cooper JA, Bauer KA, Rosenberg RD, Sato S, Kitamura A, Naito Y, Iso H, Salomaa V, Harald K, Rasi V, Vahtera E, Jousilahti P, Palosuo T, Ducimetiere P, Amouyel P, Arveiler D, Evans AE, Ferrieres J, JuhanVague I, Bingham A, Schulte H, Assmann G, Cantin B, Lamarche B, Despres JP, Dagenais GR, Tunstall-Pedoe H, Woodward M, Ben-Shlomo Y, Davey Smith G, Palmieri V, Yeh JL, Meade TW, Rudnicka A, Knottenbelt C, Ridker P, Rodeghiero F, Tosetto A, Shepherd J, Ford I, Robertson M, Brunner E, Shipley M, Feskens EJ \& Kromhout D. Plasma fibrinogen level and the risk of major cardiovascular diseases and nonvascular mortality: an individual participant meta-analysis. Journal of the American Medical Association 2005294 1799-1809.

30 Pearson TA, Mensah GA, Alexander RW, Anderson JL, Cannon RO, Criqui M, Fadl YY, Fortmann SP, Hong Y, Myers GL, Rifai N, Smith SC, Taubert K, Tracy RP \& Vinicor F. Markers of inflammation and cardiovascular disease: application to clinical and public health practice: a statement for healthcare professionals from the Centers for Disease Control and Prevention and the American Heart Association. Circulation $2003 \mathbf{1 0 7} 499-511$.

31 Festa A, D’Agostino R Jr, Howard G, Mykkanen L, Tracy RP \& Haffner SM. Chronic subclinical inflammation as part of the insulin resistance syndrome: the Insulin Resistance Atherosclerosis Study (IRAS). Circulation $2000 \mathbf{1 0 2} 42-47$.

32 Rutter MK, Meigs JB, Sullivan LM, D’Agostino RB, Sr \& Wilson PW. C-reactive protein, the metabolic syndrome, and prediction of cardiovascular events in the Framingham Offspring Study. Circulation 2004110 380-385.

33 Chrisoulidou A, Beshyah SA, Rutherford O, Spinks TJ, Mayet J, Kyd P, Anyaoku V, Haida A, Ariff B, Murphy M, Thomas E, Robinson S, Foale R \& Johnston DJ. Effects of 7 years of growth hormone replacement therapy in hypopituitary adults. Journal of Clinical Endocrinology and Metabolism $2000853762-3769$.

34 Pellitero S, Reverter JL, Pizarro E, Pastor MC, Granada ML, Tàssies D, Reverter JC, Salinas I \& Sanmarti A. Pregnancyassociated plasma protein-a levels are related to glycemic control but not to lipid profile or hemostatic parameters in type 2 diabetes. Diabetes Care 200730 3083-3085.

35 Van Harmelen V, Reynisdottir S, Eriksson P, Thorne A, Hoffstedt J, Lonnqvist F \& Arner P. Leptin secretion from subcutanous and visceral adipose tissue in women. Diabetes $1998 \mathbf{4 7} 913-917$.

36 Kristensen K, Pedersen SB, Fisker S, Norrelund H, Rosenfalck AM, Jorgensen JO \& Richelsen B. Serum leptin levels and leptin expression in growth hormone $(\mathrm{GH})$-deficient and healthy adults: influence of GH treatment, gender, and fasting. Metabolism 1998 47 1514-1519. 
37 Arita Y, Kihara S, Ouchi N, Takahashi M, Maeda K, Miyagawa J, Hotta K, Shimomura I, Nakamura T, Miyaoka K, Kuriyama H, Nishida M, Yamashita S, Okubo K, Matsubara K, Muraguchi M, Ohmoto Y, Funahashi T \& Matsuzawa Y. Paradoxical decrease of an adipose-specific protein, adiponectin, in obesity. Biochemical and Biophysical Research Communications 1999257 79-83.

38 Weyer C, Funahashi T, Tanaka S, Hotta K, Matsuzawa Y, Pratley RE \& Tataranni PA. Hypoadiponectinemia in obesity and type 2 diabetes: close association with insulin resistance and hyperinsulinemia. Journal of Clinical Endocrinology and Metabolism 200186 1930-1935.
39 Schmid C, Bianda T, Zwimpfer C, Zapf J \& Wiesli P. Changes in insulin sensitivity induced by short-term growth hormone (GH) and insulin-like growth factor I (IGF-I) treatment in GH-deficient adults are not associated with changes in adiponectin levels. Growth Hormone and IGF Research 2005 15 300-303.

Received 17 December 2007

Accepted 19 December 2007 